\title{
A Multi-Group Analysis of Risk Management Practices of Public and Private Commercial Banks
}

\author{
Khurram REHMAN ${ }^{1}$, Hadi Hassan KHAN ${ }^{2}$, Bilal SARWAR ${ }^{3}$, Noor MUHAMMAD ${ }^{4}$, \\ Wahab AHMED ${ }^{5}$, Zia Ur REHMAN ${ }^{6}$
}

Received: August 01, 2020 Revised: October 05, 2020 Accepted: October 15, 2020

\begin{abstract}
The study examines the relationship between credit risk and operational risk (understanding of risk management, risk identification, risk assessment and control, and risk monitoring) on risk management practices followed by private and public sector commercial banks. The cross-sectional data method was used to check the impact of risk management practices. Data was collected from the bank employees and a total of 284 respondents were finally selected for further analysis. Measurement Invariance of Composite Models analysis is used to test the quality of the measurement model for sub-samples, and multi-group analysis is used for path analysis in sub-sample through PLS-SEM. The findings of the study as the total sample show that both types of banks are managing adequate and significant risk management practices. On the other hand, sub-groups' results show private sector banks are more momentous than public sector banks. Risk identification is significantly different at the sub-group level, which shows public sector banks are more concentrating on this type of risk. Understanding of risk management has no significant effect on both types of banks and risk assessment \& control for public sector banks, and there is a difference in the risk management practices among private and public sector commercial banks.
\end{abstract}

Keywords: Balochistan, Commercial Banks, Measurement Invariance, Composite Models, PLS-SEM, Risk Management

JEL Classification Code: C00, C21, G21

\section{Introduction}

Financial institutions that are operating in the global environment need to devise systematic means for dealing with the challenges they face. According to Carey (2001), risk

${ }^{1}$ First Author. Lecturer, Department of Management Sciences, Al Hamd Islamic University, Quetta, Balochistan, Pakistan.

Email: khurram.rehman@alhamd.pk

${ }^{2}$ Corresponding Author. Assistant Professor, Department of Management Sciences, Faculty of Management Sciences, Balochistan University of Information Technology Engineering \& Management Sciences, Quetta, Balochistan, Pakistan [Postal Address: Jinnah Town, Samungli Road, Quetta, Balochistan, 87200, Pakistan] Email: hadihassankhan@gmail.com

${ }^{3}$ Assistant Professor, Department of Management Sciences, Faculty of Management Sciences, Balochistan University of Information Technology Engineering \& Management Sciences, Pakistan.

Email: bilal.sarwar@buitms.edu.pk

${ }^{4}$ Associate Professor, Department of Management Sciences, Faculty of Management Sciences, Balochistan University of Information Technology Engineering \& Management Sciences, Quetta, Balochistan, Pakistan. Email: noor.muhammad@buitms.edu.pk can be eliminated by anticipating all the activities with the precautionary measures of the financial institution. The risk might be exposed by the financial institution in the routine transaction and sometimes accepted to the proper flow of business activities. Over the past decades, dramatic change in the banking industry has been observed, which leads it towards an enormous loss. A well-performing financial institution suddenly announces a huge loss due to exposure to risk, such as credit risk, off-balance-sheet, etc., unable

\footnotetext{
${ }^{5}$ Lecturer, Department of Management Sciences, Muslimbagh Campus, Balochistan University of Information Technology Engineering \& Management Sciences, Quetta, Balochistan, Pakistan. Email: wahhabahmed2017@gmail.com

${ }^{6}$ Assistant Professor, Department of Management Sciences, city Campus, Balochistan University of Information Technology Engineering \& Management Sciences, Quetta, Balochistan, Pakistan. Email: ziaur.rehman@buitms.edu.pk

(c) Copyright: The Author(s)

This is an Open Access article distributed under the terms of the Creative Commons Attribution Non-Commercial License (https://creativecommons.org/licenses/by-nc/4.0/) which permits unrestricted non-commercial use, distribution, and reproduction in any medium, provided the original work is properly cited.
} 
to identify a potential factor of risk. Commercial banks all over the world facing risks from the borrowers of funds found difficulties to mitigate the risk factors (Santomero, 1997). Many principles were discussed to mitigate the risk in studies, but banks must realize the importance of risk management strategies.

Oldfield and Santomero (1995) discussed that the mitigatory strategies for risks comprise of three standards that include the elimination of risk to the business practices, transferring to others, and acceptance of the risk at the firm level. Fan and Shaffer (2004) carried out a study to find out the efficiencies against risk in the domestic banks of the USA. They concluded that the profit efficiency of the financial institution is based on both, the insolvency and the credit risks, and is independent of loan product and liquidity risk.

Risk management practices are some of the significant strategies that must be utilized specifically by banks as they ensure the enhanced operational and procedural reliability (Al-Tamimi, 2002). In the environmental dynamics presently prevailing, almost all banks are faced with many risks including credit, liquidity, foreign exchange, market, and interest rate risks, which may become a threatening source for banks (Al-Tamimi \& Al-Mazrooei, 2007). Risks present in the market are categorized into two broad kinds - systematic risk and unsystematic risk (Dang et al., 2020). After the failure of the United States investment bank Lehman Brothers on 15 September 2008 triggered the financial crisis and brought recession in the United States, which spread internationally and caused an economic crisis in the world. After these financial crises, the failure and the imperfection in the performance and poorer practices of risk management procedures were examined by the banks (Channar et al., 2015). In 2010, Shafiq and Nasr (2010) revealed that the financial institution of Pakistan commonly facing credit risk, liquidity risk, market risk, foreign exchange risk, and interest rate risk; commercial banks in Balochistan have faced the problem of operational and credit risks that lead to their enormous financial loss. The rationale for the study is to assess how much improved risk management practice is used by public and private commercial banks in Balochistan to mitigate the operational and credit risk.

This study aims to compare the practices of risk management among private as well as public commercial banks and to evaluate the extent to which commercial banks in Balochistan utilize risk management practice dealing with operational and credit risks.

\section{Literature Review}

Carey (2001) discovered new paths of the discipline of risk management through endorsing the management of financial risks, which is mandatory for all financial institutions to achieve efficiency and effectiveness. The main objective of the financial organization is the maximization of returns through achieving the capital expenditure of the organization along with simultaneously maximizing the shareholder wealth. Financial institutions offer diverse financial products and services that are full of risk, and financial institutions should adopt efficient risk management practices (Hakim \& Neaime, 2005). Rehman et al. (2019) identified risk management strategies adopted by commercial banks of Balochistan (Pakistan) and found that corporate governance, hedging, diversification, and the banks' capital adequacy ratio, are factors significantly explaining credit risk management.

Al-Tamimi and Al-Mazrooei (2007) examined the procedures and practices of risk management followed by national and international banks of UAE. They showed that UAE business banks are confronting three huge types of risks; these are foreign exchange risks pursued by operational and credit risk. The factors having the greatest influence are risk assessment and analysis, and risk identification. Moreover, the business banks of UAE have accomplished to some degree proficiency towards the management of risk. Finally, the examination inferred that the two systems, i.e., risk monitoring and controlling, fluctuate enormously between the national and international banks of UAE.

Fan and Shaffer (2004) examined the efficiencies in the local banks of the USA, concluding that the efficiency of the profit of financial institutions is based on bankruptcy and credit risk instead of the liquidity risk. Hahm (2004) directed his examination to Korea and found that the resultant profitability of investment and commercial banks of Korea was influenced by both interest and foreign exchange rate risk. A study focusing on Brunei Darussalam by Hassan (2009) identified three critical types of risks that the banks are exposed to. The first is foreign exchange risk, the second is credit risk, and the most concerning is operating risk. Furthermore, Al-Tamimi (2002) analyzed the degree to which techniques of risk management are used for taking care of various sorts of risks in the commercial banks of UAE. This research affirms that commercial banks of UAE are significantly encountering credit risk and confirm the discovery that financial statement analysis and branch managers assessment were the standard strategies utilized for risk identification.

Shafique et al. (2013) led an investigation to assess the difference in overseeing risk practices pursued by Islamic and commercial banks in Pakistan. The objective of the study was the identification of practices and procedures of risk management among banks of Pakistan. The after-effect of that investigation demonstrates no extensive variation in risk management practices (RMP) between Islamic financial institutions (IFI) and commercial financial institutions (CFI) aside from the equity investment risk. Research additionally 
finds that both financial organizations are exposed to similar kinds of risk yet at a fluctuating level. Salas and Saurina (2002) explored the credit risk in savings and commercial banks of Spain while considering both microeconomic and individual bank level factors. This fact is related to the utilization of imperative bank supervisory strategy issues, the early cautionary signs being the advantages of the bank from a different region, and the status of rivalry in banking and possession in credit risk assurance.

Masood et al. (2012) differentiate the management of credit risk between UAE Islamic and non-Islamic (commercial) banks. These research findings reveal that Islamic banks are not depending on personal experiences, but the basic credit risk analysis they are undertaking. These results demonstrate the critical effect of credit risk management of various factors and that both financial institutions are productively utilizing the practices of credit risk management. Channar et al. (2015) direct their study on commercial and Islamic banks with a survey of risk management techniques and strategies as a device for improving the organizational performance in Pakistan and analyze the connection between risk management and execution of both commercial and non-commercial banks. The investigation highlights that commercial banks are performing careful tactics for risk management with a higher standard of operational and financial performance than Islamic banks, which are progressively exposed to risk. Additionally, the studies distinguishes that there is a negative association between the management and operational execution.

Abu Hussain and Al-Ajmi (2012) examined the methodology of risk management followed by the commercial and Islamic frameworks of banking in Bahrain. The information was collected through a questionnaire to assess the understanding of risk and management, risk identification, risk assessment and analysis, and credit risk analysis. The outcome additionally demonstrates a significant and positive effect on risk management practices in both commercial and Islamic banks of Bahrain. Khalid and Amjad (2012) examined the management of risk in the Islamic banking system of Pakistan and utilized a similar model that was used by Al-Tamimi and Al-Mazrooei (2007). The exploration shows that the Islamic banking system of Pakistan positively affects risk management procedures, and the persuasive variable which demonstrated the significant behaviors was an analysis of credit risk, monitoring of risk, and knowing the risk and its management.

Oldfield and Santomero (1995) discussed three standards of the risk management procedures: the primary risk can be reduced by doing business practices essentially, furthermore transferring risk to the countering party, and finally the acknowledgment of risk. Tchankova (2002) clarifies that a risk factor is high in that part of the environment where various financial institutions are operating. Banks are the main financial institutions exceedingly connected with risk since they are managing vulnerability on a larger scale. That is the reason risk management is trialed by or given great consideration by banks to limit the potential outcomes of risk, to ensure the reliability in operations, and to find that methods are trialed by the bank. Rosman (2009) says that, given the business sectors of present-day, banks are vulnerable to a great number of risks, such as operational risk, credit risk, liquidity risk, foreign exchange risk, market risk, and interest rate risk because most banks are involving in financial activities, for example, loaning and distinctive sort of financing and investing activities.

Sarwar et al. (2020), in their study of Pakistani banks, concluded that credit risk is a significant predictor of bank margins, which is usually a key indicator of the bank's level of efficiency in terms of its fundamental role of financial intermediation. The higher the credit risk faced by banks, the greater their profitability (Dao et al., 2020).

Previous literature showed that the risk management practices used by financial institutions across the globe fluctuate depending on banking institutions and each bank faces a similar sort or magnitude of risk. This research attempts to investigate the execution of risk management practices followed by commercial banks in Balochistan (Pakistan). It is also an attempt to discover the purposes for considering six attributes: knowing the management of the risk, risk identification, risk assessment, and its analysis, controlling and monitoring of risk, and analysis of the credit risk and strategies of risk management working in Balochistan (Pakistan).

\subsection{Hypothesis Development}

The management in its verifiable way can be explained as the demonstration of the arrangement, following the paths, administration of plans that rest with top levels $f$ of management, directing, and testing for that required results. On the opposite side of the coin, the idea of risk may be clarified as the probability of any terrible or dubious occurring (Macmillan Dictionary, 2002). Almost certainly, an institution that is engaged in any business would be going against one or any other sort of risk, and most of the time is a dread, then again, there are few cases in which the occurrence is predictable. On the off chance that the banks are considered as one of such organizations, the factor of risk is definite as a result of their working in isolating conditions; their working of capacities in the lively, dissimilar, and competitive environment, they are taking an interest in the unstable financial market (Williams et al., 2006). Even though firms that face risks cannot be closed down yet it is conceivable to attenuate it by considering some determined settlement Alexander (1992). In this way, the main decision, 
for an institution like banks, is to give full attention to their management risk to decrease the probability of occurring or to diminish related penalties. These possibilities can range from "do nothing" to attempt to turn around the result of each recognized risk. (Williams et al., 2006).

\subsubsection{Understanding Risk and Risk Management}

Understanding risk management happens after the risk identification phase to understand the definite nature and strength of risk that could be taken care of through a legitimate methodology (Peter \& Peter, 2011). The impact or results, which could be driven from risk identifies previously when disregarded, can never be investigated except if the risk management is embraced. A risk assessment would concede to the systems of risk management that must be brought into utilization to regulate the expressed risk (Nazir et al., 2012). This will move out and carry the degree and cost aligned with the risk if it materializes and the related organization, at that point, uses the identified outcomes to look at the estimation of the related cost or pledgee. Much information and assessment of the risk are thus basic for the organization like a bank, which alongside settling the risk altogether furthermore shows signs of improving the bank's execution to progress safely and beneficially (Kozarević et al., 2013). Numerous types of procedures, from conventional to excessively convoluted, are utilized to gauge the diverse sorts of risks. Some of them are Value at Risk (VAR), duration analysis, and sensitivity analytics. Albeit all banking associations might come with similar risks, each might use changed methods for risk measurement, which are subject to their necessity of the issue (Kohn, 2003).

$\boldsymbol{H}_{1}:$ There is a positive relationship between understanding risk management and risk management practices.

\subsubsection{Risk Identification}

Unless the risk has not been acknowledged fundamentally, management of risk can never be executed. The above articulation clarifies that if the risk is not recognized, there will be no necessity for risk management (Vatsa, 2004). This acknowledgment can be cultivated by applying various strategies and mastery relying on the banks to build up all arrangements for both threats whether present or future that bank can confront (Pilbeam, 2018). The first and most critical step of the process of risk management procedure is the identification of the risk. If achievement is not required in this process, overseeing the risk will be prickly in the following up and coming strides of the procedure. This statement offers space to guarantee that the organization will not regard the risk, which further prompts no activities identified with it and, finally, the penalty could be very substantial (Tchankova, 2002).

$\boldsymbol{H}_{2}$ : There is a positive relationship between risk identification and risk management practices.

\subsubsection{Risk Assessment \& Analysis}

The risk evaluation assignment might be comprehended as to what is powerless against dangers and also what are the activities that can cause potential benefits or harm. It might help the bank in knowing the likelihood that the risk may happen; it is the impact on the bank and how the bank can have control over it. In this regard, the risk appraisal can be held through positioning the present risk either through assessment or examination of that chance (Williams et al., 2006). This investigative methodology is reliant on the probability of the event of a risk and the recurrence of impacts of that chance. On the opposite side of the coin, outcomes could be pondered by considering the effects on results or over the heads of results (Gastineau \& Kritzman, 1999). Communicating the normality of occurrence and its effect would give the bank the basis to know how imperative the risk may be. At the point when there is an all-around investigation, their risk assessment would be completed. An assessment is completed against reasonable criteria for risk acknowledgment to offer a prioritization.

$\boldsymbol{H}_{3}$ : There is a positive relationship between risk assessment and analysis and risk management practices.

\subsubsection{Risk Monitoring \& Control}

Risk control includes the following: different physical methods, devices, systems, strategies, and tutoring pertinent to staff to dodge, diminish, turn away or kill the claimed peril risk or its financial repercussions and related unfavorable effects of risk (Alexander, 1992). On the off chance that we think about risk in its common setting, it cannot be sidestepped or destroyed and here we are left with a sole choice, for example, control the risk the organization or the boycott faced with. Banks like different institutions have assorted traditions to prospect risks and each bank controls it by accessible devices and hypothetical instruments (Pilbeam, 2018). In every one of these banks, some may choose either to deflect the risk or to endure it and after that start hunting it down, while some different banks would settle on either exchange or protection (Vatsa, 2004). A wide distinction between attainable control level and performed control level may likewise exist. Most of the times institutions like banks, wanting to control and monitor the contemporary risk, consistently have a legitimate sketch or plan for all exercises that are practiced to manage the risk aimed that these practices exercises accomplish the 
required goal of the business for example monitoring is vital for getting the results that are at standard with the objectives set down (Gray \& Larson, 2006).

$\boldsymbol{H}_{4}$ : There is a positive relationship between risk monitoring and controlling and risk management practices.

\subsubsection{Credit Risk analysis}

Among numerous basic parts of risk management practices is how to deal with the effect of credit risk. Credit risk is situated by commercial banks throughout the world from the borrowers of funds and the banks discovered troubles to oversee credit risk. Many procedures were talked about for the management of credit risk in the investigations of numerous analysts. The Basel Committee of banking supervision (2001) characterized credit risk as to the opportunity that an extraordinary loan will be lost completely or partially when a creditor fails to honor his commitments (default risk) (Fatemi \& Fooladi, 2006). The inability to reimburse a loan is just characterized as credit risk (Giesecke, 2004; Masood et al., 2012). While considering the significance of the analysis of credit risk, the majority of the researchers considered credit risk investigation in correlation with another risk to be critical and determinant for the achievements of the financial institutions (Richard et al., 2008).

$\boldsymbol{H}_{5}$ : There is a positive relationship between credit risk analysis and risk management practices.

\section{Research Methodology}

Data has been gathered from the banking sector of Balochistan Pakistan. The target population of the study was public and private commercial banks. Only scheduled banks are considered for summing up the investigation of risk management. A total of 321 questionnaires were received of which 37 questionnaires were not appropriately filled. So, a total of 284 questionnaires were selected for analysis. The questionnaire was adopted from Al-Tamimi and AlMazrooei (2007). The survey asked the respondents to check the level of risk management implementation in public and private commercial banking frameworks. The questionnaire includes six sections such as understanding risk and risk management, risk identification, risk assessment and control, risk monitoring control, credit risk, and risk management practices.

\subsection{Scale Development}

This study is focusing on practices of risk management that are being exercised in the commercial banks of Balochistan.
To examine these aspects of risk management, the focus is on five aspects of risk management practices discussed by Al-Tamimi and Al-Mazrooei (2007), whereas the dependent variable of the study is 'risk management practices (RMP)' and independent variables of the study includes five important components of risk, namely, understanding of risk and its management (URM), risk assessment and analysis (RAA), risk identification (RI), credit risk analysis (CR) and risk monitoring and control (RMC).

\section{Data Analysis}

To achieve the research objectives, a group-level analysis was conducted through multi-group analysis (MGA) in Smart PLS (Ringle et al., 2015). The use of composites in variance-based SEM, such as PLS, is a particularly important approach in international business research to model complete theories and simultaneously estimate their cause-effect relationships (Hair et al., 2016; Sarsted et al., 2011; Sinkovics et al., 2016). The purpose of the multi-group analysis was to check the customer's perception at different levels, e.g., group1 private banks group 2 public banks in Pakistan.

The group of private sector banks consists of 167 responses, and the group of public sector banks consists of 117 responses. (PLS) partial least square estimation of the research model was used with Smart PLS 3.2.3 software (Ringle et al., 2015). The main reason for using Smart PLS was the small sample size in each group and to test the differences in the model in every three groups by using a multi-group comparison approach (MGA). Before going further Henseler et al. (2016) argued that the measurement invariance of composite models (MICOM) procedure is necessary and logical. MICOM test procedure is to test the validity and reliability at the group level and indicates that a group's level the measurement model is the same. The same variance and meaning of the measurement model for construct would imply the unbiased results (Garson, 2016) to ensure that these multi-group analyses are meaningful and lead to proper conclusions. A lack of measurement invariance suggests that the composites carry different meanings across the groups, which may be a misleading source of structural coefficients' group-specific differences (Sinkovics et al., 2016). The MICOM procedure makes findings and conclusions more comprehensive and increases the generalizability of the results.

The MICOM procedure was tested by generating 5,000 permutations in Smart PLS 3.2.3 software as suggested (Ringle et al., 2015). The configural invariance (step1) is automatically established in Smart PLS. Table 1 shows the composite invariance correlation and confidence interval the values of composite invariances of construct and the correlation value for composite invariance are equal to 1 . 
The lowest value .995 and correlation values are greater than the $5 \%$ quintile values with insignificant permutation $\mathrm{p}$ values, which show that we can proceed to the step3 of MICOM. In the next step, we evaluate the equality of means and equality of variances. Table 1 also presents the equality of means and equality of variances. The mean original differences and variance original differences values for a composite construct found between the confidence interval of $2.5 \%$ and $97.5 \%$ in both conditions so there will be full invariance and condition is satisfied.

\subsection{Reliability and Validity of the Measurements}

The first step in any SEM approach is to test the outer model (measurement model) to determine the validity and reliability of the latent construct. To check indicator reliability and internal consistency (composite reliability), convergent validity, and discriminant validity (Hair et al., 2016). Questionnaire of the study consist of 43 questions covering the six aspects of the operational and credit sides of risk. The factor loadings for indicator reliability are given in table 2 with a minimum loading was 0.68 . The satisfactory threshold for factor loading for PLS-SEM is .70 and whereby they have advised retaining items between 0.50 to 0.70 if the further construct validity and reliability may not affect (Hair et al., 2013).
Hair et al. (2011) suggested a cutoff of 0.7 and above for assessing composite reliability. The reliability of the instrument was assessed using Cronbach's alpha, Rho A, and Composite reliability. Table 2 shows the composite reliability coefficients for each of the latent constructs, which shows the adequate level of internal consistency for are variables. The assessment of convergent validity for the latent construct is recommended through average variance extracted (AVE) and the value of AVE should be at least .5 and above for latent construct (Chin, 1998; Fornell \& Larcker, 1981). Table 2 shows the adequate level of convergent validity for latent constructs in the total sample and sub-sample groups.

There are some approaches to assess the discriminant validity, like HTMT ratio, Cross loadings, and Fornell and Larcker (1981) criteria. According to Fornell and Larcker (1981) for ascertaining discriminant validity, they have suggested that the square root of the AVE should be higher than the correlations among the latent variables. Table 3 shows the discriminant validity according to Fornell and Larcker criteria. Furthermore, Henseler et al. (2015) supported the HTMT-ratio for assessing the discriminant validity by assessing the ratio value max to .85 . This indicates that the value should not exceed the .85 as strict criteria and .90 for relaxing criteria. Table 3 also reports the HTMT ratio values among the construct.

Table 1: Measurement Invariance of Composite Models (MICOM) Results for Composite Invariance

\begin{tabular}{|c|c|c|c|c|c|c|c|c|c|c|}
\hline $\begin{array}{l}\text { Composite } \\
\text { (step2) }\end{array}$ & \multicolumn{2}{|c|}{ Correlation value } & \multicolumn{2}{|c|}{ 5\% Quintile } & \multicolumn{3}{|c|}{ Permutation ( $p$-Values) } & \multicolumn{3}{|c|}{ Composite Invariance } \\
\hline CRM & \multicolumn{2}{|c|}{0.999} & \multicolumn{2}{|c|}{0.703} & \multicolumn{3}{|c|}{0.489} & \multicolumn{3}{|c|}{ Yes } \\
\hline RAA & \multicolumn{2}{|c|}{0.998} & \multicolumn{2}{|c|}{0.994} & \multicolumn{3}{|c|}{0.342} & \multicolumn{3}{|c|}{ Yes } \\
\hline RI & \multicolumn{2}{|c|}{1.000} & \multicolumn{2}{|c|}{0.999} & \multicolumn{3}{|c|}{0.600} & \multicolumn{3}{|c|}{ Yes } \\
\hline RMC & \multicolumn{2}{|c|}{0.998} & \multicolumn{2}{|c|}{0.996} & \multicolumn{3}{|c|}{0.217} & \multicolumn{3}{|c|}{ Yes } \\
\hline RMP & \multicolumn{2}{|c|}{1.000} & \multicolumn{2}{|c|}{1.000} & \multicolumn{3}{|c|}{0.962} & \multicolumn{3}{|c|}{ Yes } \\
\hline URMP & \multicolumn{2}{|c|}{0.995} & \multicolumn{2}{|c|}{0.770} & \multicolumn{3}{|c|}{0.930} & \multicolumn{3}{|c|}{ Yes } \\
\hline $\begin{array}{l}\text { Measurement } \\
\text { Invariance } \\
\text { (Step3) }\end{array}$ & MD & $2.5 \%$ & $97.5 \%$ & $p$ & VD & $2.5 \%$ & $97.5 \%$ & $p$ & EM & MI \\
\hline CRM & 0.07 & -0.243 & 0.222 & 0.61 & 0.21 & -0.36 & 0.31 & 0.20 & Yes & Full \\
\hline RAA & 0.19 & -0.237 & 0.226 & 0.31 & 0.21 & -0.40 & 0.38 & 0.33 & Yes & Full \\
\hline $\mathrm{RI}$ & -0.055 & -0.247 & 0.233 & 0.70 & 0.17 & -0.32 & 0.31 & 0.27 & Yes & Full \\
\hline $\mathrm{RMC}$ & -0.03 & -0.234 & 0.235 & 0.83 & 0.31 & -0.41 & 0.38 & 0.11 & Yes & Full \\
\hline RMP & -0.01 & -0.249 & 0.221 & 0.98 & 0.22 & -0.34 & 0.29 & 0.18 & Yes & Full \\
\hline URMP & 0.03 & -0.240 & 0.231 & 0.81 & 0.19 & -0.56 & 0.49 & 0.49 & Yes & Full \\
\hline
\end{tabular}

Note: $\mathrm{MD}=$ mean differences, $2.5 \%$, and $97.5 \%$ are lower and upper bound values, $p=$ presents the significance of mean difference, $\mathrm{VD}=$ variance differences, $\mathrm{EM}=$ equal means, and $\mathrm{MI}=$ measurement invariance . 
Table 2: Reliability and Validity

\begin{tabular}{|c|c|c|c|c|c|}
\hline Variables & Factor Loading & Alpha & Rho_A & CR & AVE \\
\hline Credit Risk Management & & 0.777 & 0.826 & 0.846 & 0.608 \\
\hline CRM1 & 0.702 & & & & \\
\hline CRM2 & 0.720 & & & & \\
\hline CRM3 & 0.710 & & & & \\
\hline CRM4 & 0.773 & & & & \\
\hline CRM5 & 0.775 & & & & \\
\hline CRM6 & 0.865 & & & & \\
\hline Risk Assessment Analysis & & 0.893 & 0.912 & 0.917 & 0.650 \\
\hline RAA1 & 0.682 & & & & \\
\hline RAA2 & 0.804 & & & & \\
\hline RAA3 & 0.796 & & & & \\
\hline RAA4 & 0.844 & & & & \\
\hline RAA5 & 0.866 & & & & \\
\hline RAA7 & 0.830 & & & & \\
\hline Risk Identification & & 0.901 & 0.910 & 0.927 & 0.718 \\
\hline RI1 & 0.899 & & & & \\
\hline $\mathrm{R} 12$ & 0.788 & & & & \\
\hline $\mathrm{RI3}$ & 0.852 & & & & \\
\hline $\mathrm{R} 14$ & 0.775 & & & & \\
\hline RI5 & 0.914 & & & & \\
\hline Risk Monitoring Control & & 0.901 & 0.910 & 0.926 & 0.716 \\
\hline RMC1 & 0.852 & & & & \\
\hline RMC2 & 0.893 & & & & \\
\hline RMC3 & 0.873 & & & & \\
\hline RMC4 & 0.826 & & & & \\
\hline RMC5 & 0.782 & & & & \\
\hline Risk management Process & & 0.939 & 0.942 & 0.952 & 0.768 \\
\hline RMP1 & 0.880 & & & & \\
\hline RMP2 & 0.898 & & & & \\
\hline RMP5 & 0.911 & & & & \\
\hline RMP6 & 0.916 & & & & \\
\hline RMP7 & 0.766 & & & & \\
\hline RMP8 & 0.879 & & & & \\
\hline Understanding Risk management & & 0.887 & 0.927 & 0.910 & 0.628 \\
\hline URMP1 & 0.759 & & & & \\
\hline URMP2 & 0.796 & & & & \\
\hline URMP3 & 0.843 & & & & \\
\hline URMP4 & 0.808 & & & & \\
\hline URMP5 & 0.773 & & & & \\
\hline URMP6 & 0.774 & & & & \\
\hline
\end{tabular}

Note: Alpha represents Cronbach's Alpha, CR represents Composite Reliability and AVE represents Average Variance Explained. 
Table 3: Discriminant Validity

\begin{tabular}{|l|c|c|c|c|c|c|}
\hline Fornell \& Larcker Criteria & CRM & RAA & RI & RMC & RMP & URMP \\
\hline CRM & 0.774 & & & & \\
\hline RAA & 0.310 & 0.806 & & & \\
\hline RI & 0.450 & 0.504 & 0.847 & & \\
\hline RMC & 0.277 & 0.696 & 0.530 & 0.846 & & \\
\hline RMP & 0.516 & 0.607 & 0.815 & 0.631 & 0.877 & 0.201 \\
\hline URMP & 0.221 & 0.184 & 0.106 & 0.158 & 0.793 \\
\hline HTMT-Ratio Criteria & CRM & RAA & RI & RMC & RMP & \\
\hline RAA & 0.234 & & & & & \\
\hline RI & 0.329 & 0.527 & & & & \\
\hline RMC & 0.194 & 0.776 & 0.579 & & & \\
\hline RMP & 0.344 & 0.635 & 0.84 & 0.678 & & \\
\hline URMP & 0.222 & 0.183 & 0.105 & 0.161 & & \\
\hline
\end{tabular}

Note: The italic and bolded values are square roots of AVE and other values are correlational values among the constructs.

Table 4: Hypothesis Testing

\begin{tabular}{|c|c|c|c|c|c|}
\hline Total Sample (284) & $\beta$ & STDEV & $T$-values & $\boldsymbol{P}$-values & Decision \\
\hline $\mathrm{CRM} \rightarrow \mathrm{RMP}$ & 0.153 & 0.036 & 4.228 & 0.000 & Supported \\
\hline $\mathrm{RAA} \rightarrow \mathrm{RMP}$ & 0.132 & 0.047 & 2.797 & 0.003 & Supported \\
\hline $\mathrm{RI} \rightarrow \mathrm{RMP}$ & 0.578 & 0.046 & 12.694 & 0.000 & Supported \\
\hline $\mathrm{RMC} \rightarrow \mathrm{RMP}$ & 0.182 & 0.045 & 4.071 & 0.000 & Supported \\
\hline URMP $\rightarrow$ RMP & 0.053 & 0.031 & 1.730 & 0.042 & Supported \\
\hline \multicolumn{6}{|l|}{ public_Sector (117) } \\
\hline $\mathrm{CRM} \rightarrow \mathrm{RMP}$ & 0.160 & 0.047 & 3.368 & 0.000 & Supported \\
\hline $\mathrm{RAA} \rightarrow \mathrm{RMP}$ & 0.083 & 0.064 & 1.286 & 0.099 & Not Supported \\
\hline $\mathrm{RI} \rightarrow \mathrm{RMP}$ & 0.641 & 0.050 & 12.790 & 0.000 & Supported \\
\hline $\mathrm{RMC} \rightarrow \mathrm{RMP}$ & 0.183 & 0.064 & 2.847 & 0.002 & Supported \\
\hline URMP $\rightarrow$ RMP & 0.053 & 0.047 & 1.116 & 0.132 & Not Supported \\
\hline \multicolumn{6}{|l|}{ Private_Sector (167) } \\
\hline $\mathrm{CRM} \rightarrow \mathrm{RMP}$ & 0.167 & 0.067 & 2.504 & 0.006 & Supported \\
\hline $\mathrm{RAA} \rightarrow \mathrm{RMP}$ & 0.194 & 0.075 & 2.599 & 0.005 & Supported \\
\hline $\mathrm{RI} \rightarrow \mathrm{RMP}$ & 0.483 & 0.080 & 6.018 & 0.000 & Supported \\
\hline $\mathrm{RMC} \rightarrow \mathrm{RMP}$ & 0.189 & 0.065 & 2.893 & 0.002 & Supported \\
\hline URMP $\rightarrow$ RMP & 0.046 & 0.047 & 0.969 & 0.166 & Not Supported \\
\hline
\end{tabular}

\subsection{Structural Model}

The structural model for the present study used standard bootstrapping procedure with 5,000 (recommended) bootstraps for a total sample of 284 cases to determine the significance of the path coefficients following
(Hair et al., 2011; Hair et al., 2012; Hair et al., 2016; Hulland, 1999). Table 4 provides full estimates of the structural model along with statistics and multi-group comparison. Which shows path coefficients group levels and differences between the groups for the relationships (Table 5). 
Table 5: Multi-Group Comparison Results

\begin{tabular}{|l|c|c|}
\hline & $\boldsymbol{\beta}$-differences & $\boldsymbol{p}$-value (difference) \\
\hline $\mathrm{CRM} \rightarrow \mathrm{RMP}$ & 0.007 & 0.466 \\
\hline $\mathrm{RAA} \rightarrow \mathrm{RMP}$ & 0.111 & 0.125 \\
\hline $\mathrm{RI} \rightarrow \mathrm{RMP}$ & -0.158 & 0.050 \\
\hline $\mathrm{RMC} \rightarrow \mathrm{RMP}$ & 0.006 & 0.480 \\
\hline $\mathrm{URMP} \rightarrow \mathrm{RMP}$ & -0.007 & 0.451 \\
\hline
\end{tabular}

Note: **significant at 0.05 (two-tail t distribution); ${ }^{* * *}$ significant at 0.01 (two-tail t distribution).

All hypotheses of the study were supported in the total sample. Table 4 showing the coefficient of all fiveindependent variables, where all are the significant measures of risk management practices for the overall sample, and public sector banks of Baluchistan whereas URMP, and RAA, has not a significant effect with risk management practice in public sector banks of Balochistan. The private sector banks of Baluchistan whereas URMP has not a significant effect on risk management practice in public sector banks of Balochistan (see table 4).

Table 5 shows the path coefficients difference and its significance. The only explanatory variable risk identification has a significant difference between the groups with the beta-difference value $(\beta=-0.158, \mathrm{p}=0.05)$. The significant negative value shows that the public sector banks have large risk identification as compare to private banks.

Furthermore, credit risk management, Risk management control, and understanding risk management have the smallest coefficient difference which indicates that both types of banks have the same type risk management for these risk indicators (table 5).

\section{Discussion and Conclusion}

Past studies (Abu Hussain \& Al-Ajmi, 2012; AlTamimi \& Al-Mazrooei, 2007; Alexander, 1992; Barnhill Jr, Papapanagiotou, \& Schumacher, 2002; Carey, 2001; Channar et al., 2015; Hahm, 2004; Hassan, 2009) identified credit risk and foreign exchange risk as to the most important types of risk in their studies. Whereas considering the need to further explore the more related element that might be antecedent of RMP, this study was conducted. A study finding is discussed in this chapter.

Hypothesis 1 was supported by the results of the study, which postulates that there exists a positive relationship between understanding risk management and risk management practices followed by the public as well as private commercial banks of Balochistan. This is so, since the strength of impact or results, which could be driven from risk previously identified, once ignored, can never be reviewed unless the risk management is adopted (Rosman, 2009).
Al-Tamimi and Al-Mazrooei (2007), found that the UAE bank staff have great risk understandings and risk management, which may give a sign about the capacity of these banks to manage risks effectively in the future. Nazir et al. (2012), found URM as a significant measure of RMP. Past research (Abu Hussain \& Al-Ajmi, 2012; Carey, 2001; Hassan, 2009; Khalid \& Amjad, 2012) shows that URM is a significant measure of RMP, but the nature of the relationship yet not discussed. This study extends the work by Abu Hussain and Al-Ajmi (2012); Al-Tamimi and Al-Mazrooei (2007); Carey (2001); Channar et al. (2015); Hassan (2009) that shows that URM and RMP are positively related to each other.

In hypothesis 2, it was specified that there exists a positive relationship between identification of risk and the risk management procedures followed by the public as well as private commercial banks of Balochistan. Results confirmed that there is a significant positive relationship between RI and RMP. Al-Tamimi (2002) found RI is a potential component in RMP, and failure to identify the risk increases the chances to expose to risk. The result of this study supports the findings of previous research (Abu Hussain \& Al-Ajmi, 2012; Alexander, 1992; Carey, 2001; Channar et al., 2015; Nazir et al., 2012) indicating that RI and RMP are positively related to each other. While comparing previous studies and the results of this study confirmed that there is a significant positive relationship between RI and RMP followed by private and public commercial banks.

Hypothesis anticipated that there exists a positive relationship between risk assessment and analysis (RAA) and the risk management practice (RMP) followed by public and private commercial banks of Balochistan. This study found a positive relationship between RAA and RMP and considered RAA a very important element of RMP. RAA is valuable to characterize the extraordinary risk as indicated by the degree of mutilation they perhaps cause. The measures are utilized not just for risk control purposes, yet in addition to the measurement of performance, it found RAA is the essential component for RMP for financial institutions. So, the findings of this study confirm the hypothesis that there is positivity in the practicing of risk RAA and RMP, but a private commercial bank of Balochistan is more efficient 
in the practices of whereas public sector banks are facing difficulties in assessing the potential risk. Hence, this study extends the findings of past research to private commercial banks by highlighting the positive relationship between RAA and RMP, which was missed in the literature according to our limited knowledge (Al-Tamimi \& Al-Mazrooei, 2007; Drzik, 1995; Hassan, 2009).

Hypothesis 4 stated that there exists a positive relationship between monitoring and controlling the risk and risk management procedures followed by the public and private commercial banks of Balochistan. A sound reporting and review structure is a pre-requisite for ensuring that efficient identification and assessment of risks could be done and that adequate control and response mechanism are functioning. Several studies found a positive relation between RMA and RMP (Alexander, 1992; Carey, 2001; Khalid \& Amjad, 2012). However, previous research (Bowerman \& O'connell, 1990; Fan \& Shaffer, 2004; Hassan, 2009; Nazir et al., 2012; Shafiq \& Nasr, 2010; Shafique et al., 2013), indicated RMA and RMP are not positively related to each other. So, the findings conclude that public and private commercial banks significantly differ in the practices of RMA. For a private commercial bank, there is a positive relationship between RMA and RMP and vice versa for public sector commercial banks of Balochistan.

Hypothesis 5 is anticipated that CRA and RMP would be positively correlated, followed by the public as well as private commercial banks of Balochistan. Moreover, research (Fatemi \& Fooladi, 2006; Giesecke, 2004; Masood et al., 2012; Peter \& Peter, 2011; Salas \& Saurina, 2002) counts credit risk analysis as a key factor for the performance of the financial institution and also found a positive relationship between CRA and RMP. The result indicates that, if credit risk was not assessed timely, this will harm bank performance severely and most of the time leads to the insolvency of the institutions (Abu Hussain \& Al-Ajmi, 2012; Al-Tamimi \& Al-Mazrooei, 2007). Kozarević et al. (2013), found that Bosnian commercial banks were mainly challenged by loan default risk or credit risk. Richard et al. (2008) state that Tanzanian commercial banks are affected by credit risk.

While reviewing past research (Abu Hussain \& AlAjmi, 2012; Barnhill Jr et al., 2002; Fatemi \& Fooladi, 2006; Giesecke, 2004; Kozarević et al., 2013; Masood et al., 2012; Richard et al., 2008; Salas \& Saurina, 2002; Santomero, 1997), the verdict of this study concluded that the private sector commercial banks of Balochistan significantly manage credit risk, whereas it is an alarming indicator for public sector banks because they might be affected enormously if they continue practicing the way they do. Thus, the key findings of the study state that there is a positive relationship between CRA and RMP for private commercial banks, while it was not found for public sector commercial banks.
As the results suggest that public banks potentially identify the risk and have enough awareness of understanding risk management, but are still exposed to risk just because of the application of risk monitoring and assessment of risk. Another difference between public and private commercial banks is the evaluation of credit risk. Results show that private commercial banks are practicing better strategies than public banks to minimize the exposure to credit risk. Credit risk is the most important element of risk management practices because if it is not potentially identifying that this will leads to liquidity problems. Public banks are government banks and they are practicing most of the government policies and these policies are highly risky. This could be a reason that public sector banks are more exposed to credit risk than private sector banks. So, public banks should adopt the risk management procedure of private commercial banks or revisit their procedures and should develop new paths for risk management practices to minimize the probability of being exposed to risk. Public sector commercial banks also need a strict internal control system for the evaluation of their operational and credit department staff, so they should fulfill all the precautionary measures that can minimize the chances of risk.

In summary, the research concludes that ensuring the risk management strategies is not only for minimizing the chances of occurrence of the risk, but it could be a significant reason for increasing the profitability for banks and might be useful for getting a competitive edge over other banks. The results also indicate that risk identification has higher impact in public sector commercial banks.

\section{Future Recommendations}

The study has some limitations, particularly, related to its methodology used and generalization of the result as it is a comparative study among the commercial banks of Balochistan with limited sample size. However, it can be used as evidence for all cases being witnessed in a different part of the banking industry. However, it could be considered a case study of the commercial side of the banking industry of Pakistan. Finally, it is difficult to cover all facets of risk management in financial institutions, risk management practices can be affected by economic factors, regulations, high and low liquidity position, and Basel.

\section{References}

Abu Hussain, H., \& Al-Ajmi, J. (2012). Risk management practices of conventional and Islamic banks in Bahrain. The Journal of Risk Finance, 13(3), 215-239. doi: https://doi. org/10.1108/15265941211229244

Al-Tamimi. (2002). Risk management practices: an empirical analysis of the UAE commercial banks. Finance India, 16(3), 1045-1057. 
Al-Tamimi, \& Al-Mazrooei, F. M. (2007). Banks' risk management: a comparison study of UAE national and foreign banks. The Journal of Risk Finance Incorporating Balance Sheet, 8(4), 394-409. doi: https://doi.org/10.1108/15265940710777333

Alexander, K. (1992). Facilities management practice. Facilities, 10(5), 11-18. http://dx.doi.org/10.1108/EUM0000000002189

Barnhill Jr, T. M., Papapanagiotou, P., \& Schumacher, L. (2002). Measuring integrated market and credit risk in bank portfolios: An application to a set of hypothetical banks operating in South Africa. Financial Markets, Institutions \& Instruments, 11(5), 401-443. https://doi.org/10.1111/1468-0416.11502

Bowerman, B. L., \& O'connell, R. T. (1990). Linear statistical models: An applied approach. Pacific Grove, CA: Brooks/Cole.

Carey, A. (2001). Effective risk management in financial institutions: the turnbull approach. Balance Sheet, 9(3), 24-27. doi: https://doi.org/10.1108/09657960110696014

Channar, Z. A., Abbasi, P., \& Maheshwari, M. B. (2015). Risk Management: A tool for enhancing organizational performance. Pakistan Business Review, 17(1), 1-20.

Chin, W. W. (1998). The partial least squares approach to structural equation modeling. Modern Methods for Business Research, 295(2), 295-336.

Dang, H. T., Phan, D. T., Nguyen, H. T., \& Hoang, L. H. T. (2020). Factors Affecting Financial Risk: Evidence from Listed Enterprises in Vietnam. Journal of Asian Finance, Economics and Business, 7(9), 11-18. https://doi.org/10.13106/jafeb.2020. vol7.no9.011

Dao, B. T. T., Nguyen, D. P., Pienkhuntod, A., Amornbunchornvei, C., Nantharath, P., Yooyanyong, P., . . Tangjitprom, N. (2020). Determinants of Profitability in Commercial Banks in Vietnam, Malaysia and Thailand. Journal of Asian Finance, Economics and Business, 7(4), 133-143. https://doi.org/10.13106/ jafeb.2020.vol7.no4.133

Drzik, J. (1995). CFO Survey: Moving Towards Comprehensive Risk Management. Bank Management, 71(4), 34-59.

Fan, L., \& Shaffer, S. (2004). Efficiency versus risk in large domestic US banks. Managerial Finance, 30(9), 1-19. doi: https://doi.org/10.1108/03074350410769245

Fatemi, A., \& Fooladi, I. (2006). Credit risk management: a survey of practices. Managerial Finance, 32(3), 227-233. doi: https:// doi.org/10.1108/03074350610646735

Fornell, C., \& Larcker, D. F. (1981). Evaluating structural equation models with unobservable variables and measurement error. Journal of Marketing Research, 18(1), 39-50. doi: https://doi. org/10.1177/002224378101800104

Garson, G. D. (2016). Partial least squares: Regression and structural equation models. Asheboro, NC: Statistical Associates Publishers.

Gastineau, G. L., \& Kritzman, M. P. (1999). Dictionary of financial risk management (Vol. 52). Hoboken, NJ: John Wiley \& Sons.
Giesecke, K. (2004). Credit risk modeling and valuation: an introduction. Credit Risk: Models and Management (Vol. 2). New York, NY: Risk Books.

Gray, C. F., \& Larson, E. W. (2006). Organization strategy and project selection. In: Project management: the managerial process (3rd ed). New York, NY: McGraw-Hill.

Hahm, J.-H. (2004). Interest rate and exchange rate exposures of banking institutions in pre-crisis Korea. Applied Economics, 36(13), 1409-1419. https://doi. org $/ 10.1080 / 0003684042000206979$

Hair, J. F., Ringle, C. M., \& Sarstedt, M. (2011). PLS-SEM: Indeed a silver bullet. Journal of Marketing Theory and Practice, 19(2), 139-152. https://doi.org/10.2753/MTP1069-6679190202

Hair, J. F., Ringle, C. M., \& Sarstedt, M. (2013). Partial least squares structural equation modeling: Rigorous applications, better results and higher acceptance. Long Range Planning, 46(1-2), 1-12.

Hair, J. F., Sarstedt, M., Ringle, C. M., \& Mena, J. A. (2012). An assessment of the use of partial least squares structural equation modeling in marketing research. Journal of the Academy of Marketing Science, 40(3), 414-433. doi: https:// doi.org/10.1007/s11747-011-0261-6

Hair Jr, J. F., Hult, G. T. M., Ringle, C., \& Sarstedt, M. (2016). A primer on partial least squares structural equation modeling (PLS-SEM). Los Angeles, CA: Sage Publications.

Hakim, S., \& Neaime, S. (2005). Profitability and risk management in banking: a comparative analysis of Egypt and Lebanon Money and Finance in the Middle East: Missed Opportunities or Future Prospects? (Vol. 6, pp. 117-131). Emerald Group Publishing Limited.

Hassan, A. (2009). Risk management practices of Islamic banks of Brunei Darussalam. The Journal of Risk Finance, 10(1), 23-37. doi: https://doi.org/10.1108/15265940910924472

Henseler, J., Ringle, C. M., \& Sarstedt, M. (2015). A new criterion for assessing discriminant validity in variance-based structural equation modeling. Journal of the Academy of Marketing Science, 43(1), 115-135. https://doi.org/10.1007/s11747-0140403-8

Henseler, J., Ringle, C. M., \& Sarstedt, M. (2016). Testing measurement invariance of composites using partial least squares. International Marketing Review. https://doi. org/10.1108/IMR-09-2014-0304

Hulland, J. (1999). Use of partial least squares (PLS) in strategic management research: A review of four recent studies. Strategic Management Journal, 20(2), 195-204. https://doi.org/10.1002/ (SICI)1097-0266(199902)20:2<195::AID-SMJ13>3.0.CO;2-7

Khalid, S., \& Amjad, S. (2012). Risk management practices in Islamic banks of Pakistan. The Journal of Risk Finance, 13(2), 148-159. https://doi.org/10.1108/15265941211203198

Kohn, M. (2003). Financial Institutions and Markets (2 ed.). New York, NY: Oxford University Press. 
Kozarević, E., Nuhanović, S., \& Nurikić, M. B. (2013). Comparative analysis of risk management in Conventional and Islamic Banks: the case of Bosnia and Herzegovina. International Business Research, 6(5), 180-193. http://dx.doi.org/10.5539/ ibr.v6n5p 180

Masood, O., Al Suwaidi, H., \& Darshini Pun Thapa, P. (2012). Credit risk management: a case differentiating Islamic and non-Islamic banks in UAE. Qualitative Research in Financial Markets, 4(2/3), 197-205. https://doi.org/10.1108/17554171211252529

Nazir, M. S., Daniel, A., \& Nawaz, M. M. (2012). Risk management practices: A comparison of conventional and Islamic banks in Pakistan. American Journal of Scientific Research, 68(1), 114122.

Oldfield, G. S., \& Santomero, A. M. (1995). The place of risk management in financial institutions (Vol. 39): Wharton School, University of Pennsylvania.

Peter, V., \& Peter, R. (2011). Risk management model: an empirical assessment of the risk of default. Journal of Risk and Diversification (1), 6-18.

Pilbeam, K. (2018). Finance \& financial markets (4th ed.). New York, NY: Macmillan International Higher Education.

Rehman, Z. U., Muhammad, N., Sarwar, B., \& Raz, M. A. (2019). Impact of risk management strategies on the credit risk faced by commercial banks of Balochistan. Financial Innovation, 5(1), 44. doi: https://doi.org/10.1186/s40854-019-0159-8

Richard, E., Chijoriga, M., Kaijage, E., Peterson, C., \& Bohman, H. (2008). Credit risk management system of a commercial bank in Tanzania. International Journal of Emerging Markets, 3(3), 323-332. https://doi.org/10.1108/17468800810883729

Ringle, C. M., Wende, S., \& Becker, J.-M. (2015). SmartPLS 3. Boenningstedt: SmartPLS GmbH.

Rosman, R. (2009). Risk management practices and risk management processes of Islamic banks: a proposed framework. International Review of Business Research Papers, 5(1), 242-254.

Salas, V., \& Saurina, J. (2002). Credit risk in two institutional regimes: Spanish commercial and savings banks. Journal of Financial Services Research, 22(3), 203-224. https://doi. org/10.1023/A:1019781109676

Santomero, A. M. (1997). Commercial bank risk management: an analysis of the process. Journal of Financial Services Research, 12(2/3), 83-115. https://doi.org/10.1023/A:1007971801810

Sarstedt, M., Henseler, J., \& Christian, M. (2011). Multi-Group Analysis in Partial Least Squares (PLS) Path Modeling: Alternative Methods and Empirical Results. Advances in International Marketing, 22, 195-218.

Sarwar, B., Muhammad, N., \& Zaman, N. U. (2020). Diversification, industry concentration, and bank margins: Empirical evidence from an emerging south Asian economy. Journal of Asian Finance, Economics, and Business, 7(7), 349-360. https://doi. org/10.13106/jafeb.2020.vol7.no7.349

Shafiq, A., \& Nasr, M. (2010). Risk management practices followed by the commercial banks in Pakistan. International Review of Business Research Papers, 6(2), 308-325.

Shafique, O., Hussain, N., \& Hassan, M. T. (2013). Differences in the risk management practices of Islamic versus conventional financial institutions in Pakistan: An empirical study. The Journal of Risk Finance, 14(2), 179-196. https://doi. org/10.1108/15265941311301206

Sinkovics, R. R., Henseler, J., Ringle, C. M., \& Sarstedt, M. (2016). Testing measurement invariance of composites using partial least squares. International Marketing Review, 33(3), 405-431.

Tchankova, L. (2002). Risk identification-basic stage in risk management. Environmental Management and Health, 13(3), 290-297. https://doi.org/10.1108/09566160210431088

Vatsa, K. S. (2004). Risk, vulnerability, and asset-based approach to disaster risk management. International Journal of Sociology and Social Policy, 24(10/11), 1-48. https://doi. org/10.1108/01443330410791055

Williams, R., Bertsch, B., Dale, B., Van Der Wiele, T., Van Iwaarden, J., Smith, M., \& Visser, R. (2006). Quality and risk management: what are the key issues? The TQM Magazine, 18(1), 67-86. https://doi.org/10.1108/09544780610637703 